\title{
Excursions
}

Volume 5, Issue 1 (December 2014) Boundaries

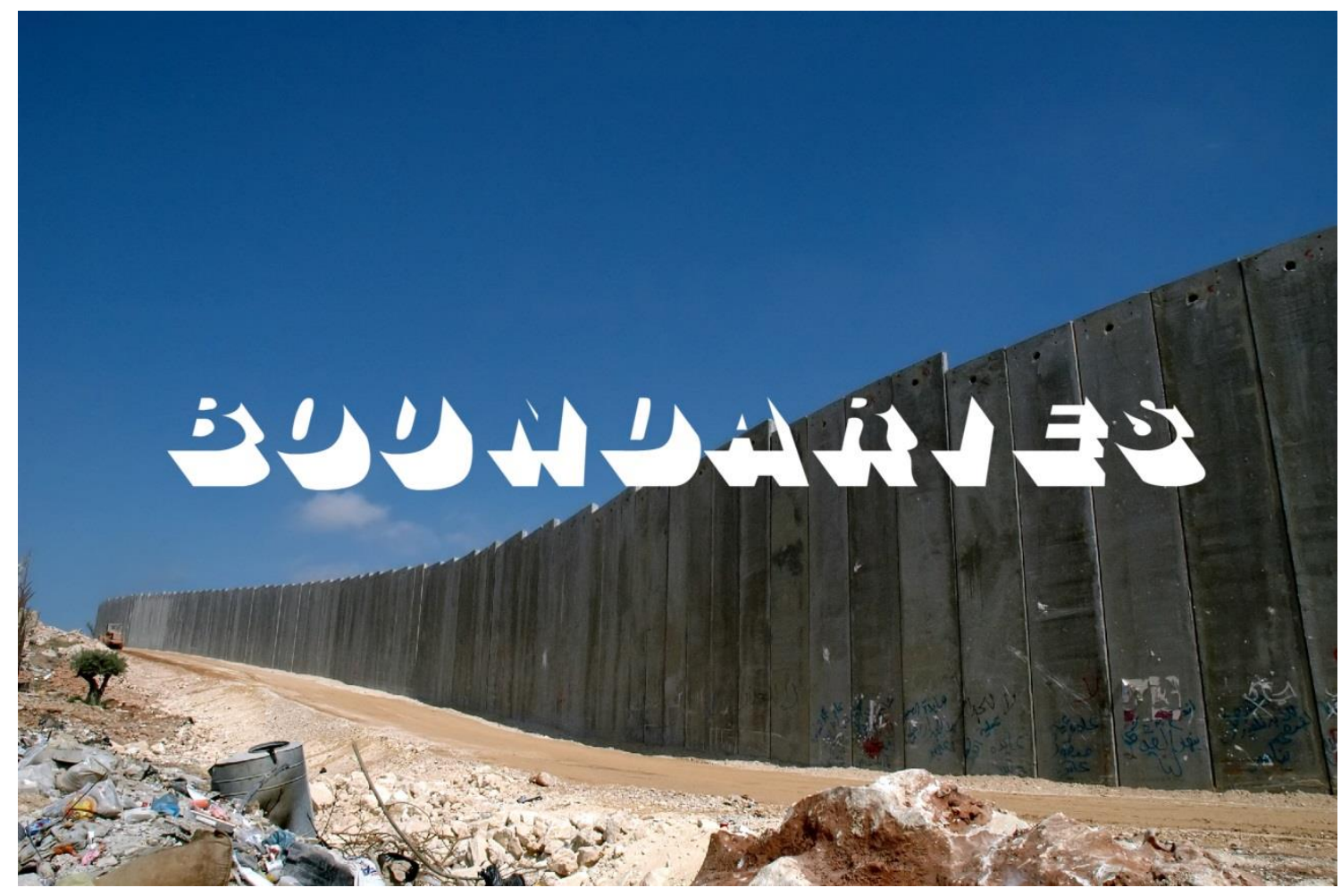

Cover photo: Justin Mclntosh

Cover design: Danny Bright

Nigel Morris, 'Boundaries Unbound: Jude, Adaptation and Assemblages'

Excursions, vol. 5, no. 1 (2014)

www.excursions-journal.org.uk/index.php/excursions/article/view/172 
Nigel Morris

University of Lincoln

\section{Boundaries Unbound: Jude, Adaptation and Assemblages}

Most commercial films are hybrid, at boundaries of two or more genres. Literary adaptations, moreover, seemingly straddle media and their study crosses disciplines. Examination here of Jude (Winterbottom, 1996) attempts an innovative analysis of paratextual and peritextual features to account for its emergence and subsequent fortunes. These exceed directorial vision, consciously conflated styles, and alleged 'fidelity' or otherwise to its 'source', but conjoin taste formations, conflicting commercial strategies, contrasting audiences and modes of address, and yoke together institutional models, each with its distinctive ethos, of financing, production, and distribution. Like any text, Jude is a contingent product of time and place. Disappointing takings following inappropriate promotion, despite critical praise and enduring admiration, are, this paper contends, explicable by Jude's positioning at the boundary between markets; shortly before, this would have been refreshing and radical, but in just months between conception and release its commercial context altered irrevocably. 


\section{Introduction}

As adaptation, Jude occupies a boundary between literature and film, which, by definition, acknowledges change. The present writer observes elsewhere that adaptation

cannot be neutral transposition between media, for elements such as theme, character, plot, and symbolism have no existence outside their activation in decoding. Meaning is produced through signification, the interplay of signs activated by the reader bringing to bear his or her own discursive formation, including knowledge of codes (1996, p.609).

Yet perception of difference between sources and adaptations is the popular and academic default, favouring the original. Inevitably, as Thomas Leitch observes, 'source texts will always be better at being themselves' (2003, p.161).

Interpretations - of sources and adaptations - are unique. Intertextuality exceeds lineage implied in similar titles or associated publicity. Robert Stam (2005) reviews approaches to scores of adaptations, texts interweaving innumerable discourses, read or watched by many thousands. From adaptations' 'sheer volume', nobody 'could do justice to their diversity' (Collins, 2010, p.121). Ambivalences, personnel, institutions, budgets, and audiences entail different changes. This precludes neither exegesis nor identification of problems, nor denies adaptation's frequent centrality to production, marketing, and reception. Studying these, given the paucity of 'contemporary adaptation theory' (Leitch, 2003, p.149), negotiates boundaries which reinstate 'oppositions that poststructuralist theory has taught us to deconstruct' (Naremore, 2000, p.2), including book/reader; film/spectator; public service/commerce; texts/paratexts; art/entertainment; high/low culture; tradition/innovation; expectation/experience; and boundaries within narratives. Assumptions, 'rarely articulated' (Leitch, 2003, p.150), about relations between literature and film and associated disciplines, can, consciously and critically considered, highlight determinants of meaning. Beyond difficulties in crossing subject boundaries, many literary critics consider canonical refashioning inherently inferior, rendering adaptation pointless, while media scholars eschew evaluative approaches.

Jude, envisioned from Thomas Hardy's Jude the Obscure (1895), gained awards, then relative oblivion. Timing affected its distinctiveness, reception, and unprofitability. Tendencies that facilitated financing clashed with emergent 
marketing and taste formations. This paper considers Jude's conception in an ostensibly, if oxymoronically, 'non-commercial' ethos before release into another. Essentially, Jude was created by cinephiles but promoted into a seismically changing literary-oriented market: from heritage cinema to what Jim Collins terms 'cineliterary' culture.

\section{Background}

Art cinema downplayed adaptations; autonomous works had auteurs and criteria unsullied by popularity, profits, or mainstream culture. Film academics ignored adaptation; literary assumptions, including authorship, compromised their discipline's particularity. Some literary scholars examined adaptations, to embrace theory or make novels attractive to students - presupposing writing's primacy, hence, implicitly, superiority.

Difficult literature engendered a 'priestly industry of explicators, annotators, allusion chasers to mediate' with readers (John Barth, quoted in Collins, 2010, p.20); such 'religious tropes', Collins explains, typify culture 'within a profane society' as 'transcendent' - rarified 'by restricting access' (p.20). Arthouse cinema's distribution, esoteric festivals, and auteurist marketing establish comparable boundaries. Antipathetic literary criticism and film studies perpetuate similar tendencies. Hybrid, populist, cine-literary culture, Collins argues, sidelined each. This emerged during Jude's production.

Understanding Jude's status demands flexibility. No methodology universally explains adaptation and associated debates, or embraces production and reception. Here, pragmatically, textual analysis identifies interpretive and critical determinants, ordering what might, detached from experiences requiring explanation, become unwieldy. First, the trailer interpellates potential audiences, suggesting meanings confirmed or subverted. A membership boundary, it prefigures how any film 'causes the spectator [...] to identify not only the terms of the presentation but to recognize herself as the effective addressee' (Casetti, 1998, p.14). The film's opening 'boundary ritual' (Fiske and Hartley 1978, p.165) - credits and enigma, inaugurating cinema's spectatorial dream state or separating a broadcast from flow and continuity - invokes multiple contexts. Meshing interpretation and observation onto the bundled novel and film, and production, promotion, and reception, this study criss-crosses 
boundaries: between reconstructed, freeze-framed viewing; retrospective, contextual knowledge; and critical apparatus.

Jude manifests entanglements unique to every text, including determinants of content and value in pre-history, release context, and consequent fortunes. Contestable meanings necessitate analysis, despite Simone Murray rejecting 'adaptation studies' wearyingly familiar methodology': case studies predicated on exceptionalism (2012, p.178). Typicality is an ideal; texts occupy unique ecosystems. Murray's materialism clarifies who commissions and realizes adaptations; why, how and when markets and institutions select and treat texts. It acknowledges policy, production study, and institutional slants. One challenge is to identify and explain discourses - transposable, if little else is - their origins and implications.

Tim Ingold (2010) invokes Gilles Deleuze and Félix Guattari to explore creativity. Ingold substitutes process for product, exceeding, although complementing, Leitch's conception of adaptation as 'work-in-progress of institutional practices of rewriting' (2007, p.303). Deleuze and Guattari's key image, the rhizome, describes 'becoming' and provisional 'assemblages' and meanings. 'Things' occur where 'growth and movement' (Ingold, 2010, p.3), innumerable arbitrary lines of force, entangle. Deleuze and Guattari challenge 'arborescence' (2004, pp.3-28), which schematizes identity (but much else) historically, culturally rooted, as tree-like: ancestral couplings leading to the self, descendants branching, behaviour spreading consequentially, yet persons considered unique.

Ingold discusses a tree's inseparability from systems reciprocally sustained and contained. Boundaries are permeable. Plants territorialize where ground (zone, not surface) meets atmosphere (gases intermixing), changing both: interacting minerals, moisture, sunlight, air, gravity, other life. Analogously, where do films meet informing culture? Reading determinants include paratexts - precedent epitexts (trailers, posters, interviews, reviews, other promotion and publicity) and contiguous peritexts (classification certificates, distributors' cards, logos, titles, credits); stars; genres; schedules, theatres, or domestic habits accommodating screening; fellow viewers; historical, political, and economic circumstances. Intertextuality renders untenable that texts guarantee meaning. It denotes selected bundles among countless discourses. Links are less hypertextual connections than adjacencies in assemblage nodes; interfaces to cross, penetrate, join, unscramble; juxtapositions and frictions; patterns unravelling, merging, emerging, inert or sparking together. Materialism 
traces and augments 'flows', 'paths of form-generation' (Ingold, 2010, p.3). Improvising routes, researchers posit structurations not exclusively textual: 'the exteriority of forces and relations' (Deleuze, 1977, p.12).

Such musings echo fidelity's diminution within adaptation studies. If, Robert Lapsley and Michael Westlake synopsize, existence comprises 'endless variation, an open-ended dynamic process of energies and forces [...] nothing is produced in a final form' (2006, p.245). Deleuze and Guattari frequently invoke an orchid and the indistinguishable wasp feeding upon predators. Biologically - and once, evolutionarily - separate, identical, yet distinctive members of discrete taxonomies as well as in purposeful (yet once random) congruity, they thrive interdependently: a rhizomic assemblage. The wasp pollinates, ensuring survival through reproduction; the orchid camouflages, ensuring survival for reproduction. Prioritizing either, without considered criteria, is futile.

'[A]ny point of a rhizome can be connected to any other, and must be', necessitating fragmentary, provisional structuration (Deleuze and Guattari, 2004, p.7). What follows are not separate notes but tendrils in assemblage: segments extending shoots, folding back on, twisting around, slipping past or snagging upon others.

\section{Trailer}

The trailer ${ }^{1}$ intersperses titles among disordered clips. Purposed to create desire, not summarize, it necessitates viewing the movie for coherence. Francesco Casetti observes: 'a film designates its spectator by structuring his presence [...] the way it says you' (1998, p.15). Typically this starts in advance.

\section{PolyGram}

FILMED ENTERTAINMENT

PolyGram (PFE), Britain's foremost financier and distributor (Murphy, 2000), exported low-budget movies. The small domestic market necessitated American distribution for projects over two million dollars. Some, including 'quality costume drama', succeeded despite precarious investment and disconnected production, distribution, and exhibition (Higson, 2003). 
'Entertainment' implies diversion. Yet cinema claims seriousness: hence publicity bodies named 'Academies'. Producers exploit 'need for uplifting subject matter' (Collins, 2010, p.124) while gaining from 'pre-sold' copyright-free literary titles. Adaptations from valued texts assert respectability.

Despite brand recognition, British films are not easily definable in a multinational industry. Theatrical release generates publicity before television screening. Profitable titles occasionally become mainstream. Chariots of Fire (Hudson, 1981) and A Room With a View (Ivory, 1985) garnered Goldcrest Films seven Oscars. Coinciding with esteemed broadcast adaptations, these heralded popular period dramas characterized by 'authorship, craft, and artistic value', feted for 'cultural significance' (Higson, 2003, p.8). Nevertheless, before 1990s' 'adaptation mania', their specialisation rendered them 'never in danger of winning Best Picture or enjoying blockbuster-calibre' box-office (Collins, 2010, pp.120, 143).

Thatcherite 'enterprise culture' meanwhile marketed a safely commodified and objectified past; stately homes represented architecture, not power. While such places no more embodied domestic sightseers' history than overseas visitors', the official version was widely consumable. Robert Hewison (1987) argued that heritage industry's' preserving or revering history evades discontent, replacing contradictions with illusory permanence. Against manufacturing decline and technological and social change, 'heritage' films suffered vilification as conservative.

Heritage practices intertwine with 'physical' or 'material' heritage. Fictionalized settings, or authors' lives, evoke places. Filming locations serve tourism. Accordingly, various industries - reviewing, criticism, publishing, education, advertising, other adaptations - shaped Hardy: ideologically selecting, while claiming to reproduce, meanings, including "naturalized acceptance that "rural nostalgia" is inscribed in Hardy, not constructed as "Hardy"' (Widdowson, 1989, p.88).

Howards End (Ivory, 1992), 'safe, respectable and properly British', achieved 'cultural prominence' (Higson, 2003, p.146). The eight million dollar production earned 52,568 dollars weekend takings on one screen before grossing 25,967,000 dollars across North America. A Room With a View had established a pattern: expanding from one theatre with minimal advertising, it fuelled a year's upmarket journalism. 'Word of mouth' engendered exposure. Limited prints served cumulative audiences cheaply, avoiding competition with mainstream studios for block bookings 
(Murray, 2012). Fewer theatres required payment - before vying for a must-see success.

By the late 1990 major studios had 'specialty' affiliates. Bridging 'independent' and mainstream boundaries, alternatives to blockbusters targeted niche audiences (Higson, 2003), diversified risk, and permitted innovation. 'British' successes including Much Ado About Nothing (Branagh, 1993) and Sense and Sensibility (Lee, 1996) were US-funded and targeted. Regionality and nationality, supposedly expressing identity, became global images created and exchanged elsewhere.

Literary cinema infiltrated multiplexes and Best Picture status, 'exponentially' broadening audiences, shifting taste, expectations, and values (Collins, 2010, p.144), effacing boundaries between art and commerce, seriousness and pleasure. Sexual frankness associated with '[a]rt cinema' joined lifestyle qualities associated with period drama, including culinary, clothing, decorating, and tourism fads. Further overlap occurred with popular romance: 'cine-literary' consumption conflates 'quality literature with quality passion' - after all, each each 'sweeps you away' (164). This possibly explains Jude's preposterous Internet Movie Database summary: 'A stonemason steadfastly pursues a cousin he loves. However [...] she is married to an abusive nobleman'.

White on black titles utilize bookish type:

\section{From The Classic Novel \\ by \\ THOMAS HARDY}

'Classic' implies canonicity and seriousness. Launched contemporaneously with Jude, Oprah's Book Club, globally influential on publishing, exemplifies cultural capital's marketability. Collins characterises such boundary crossings as finishing schools in taste, compensating for mass higher education's failure to effect personal transformation.

Enigmatically withholding the title attracts filmgoers interested in Hardy while evoking recognition from those aware of it yet delaying confirmed 'insider' identity. 
A Major Screen

Adaptation

Routine hyperbole - nobody promotes minor adaptations - proclaims prestige and Awards potential. Jude's budget, fifteen per cent above that year's British average, conferred marketable stature.

A Love

Beyond Measure

Paradox reinforces the hermeneutic. The indefinite article renders love countable. Whose? What kind? Implying a standard asserts this instance's uniqueness accordingly, the film's. Equating 'transcendent [...] rapturous love of literature' with 'the most refined [...] sexual passion' increasingly characterised literary movies (Collins, 2010, p.150).

\section{A Love Story}

Without Equal

Jude's trailer evokes heritage, wherein romance suggests 'the woman's picture' (Higson, 2003). Dialogue implicates familial, romantic, sexual, and legal relationships, male scopophilia, and Sue's proto-feminism. 'Without Equal' reiterates exceptionality: surpassing convention. Contradictorily, Phillotson (Liam Cunningham) introduces melodrama's cliché of a woman torn between lovers. Genre balances familiarity against distinctiveness. Arabella (Rachael Griffiths) remains unmentioned. Christminster ambitions and associated obstacles feature only jokingly: Jude is 'scholar' and 'sinner'. Class boundaries, connoting realism or politics, are unstressed.

\section{Christopher \\ ECCLESTON}

Eccleston trailed glory from BAFTA Best Film Shallow Grave (Boyle, 1994) and BBC2's prestigious Our Friends in the North (1996), originally a Royal Shakespeare 
Company project. He connoted respectability from Jimmy McGovern's Cracker (1993-4) and Hearts and Minds (1995), 'serious' television being a writer's medium. All addressed 'the state of the nation': one of Jude's provocations, a century after Hardy.

\section{Kate WINSLET}

Jude was Winslet's third film. Heavenly Creatures (Jackson, 1994), admired on festival and independent circuits planned for Jude, conferred 'cult' prominence (Widdowson, 1997, p.101). Winslet was Oscar-nominated Best Supporting Actress for Sense and Sensibility. This co-starred Emma Thompson - whose script won Best Adapted Screenplay - also Best Actress for Howards End. These associations positioned Jude similarly.

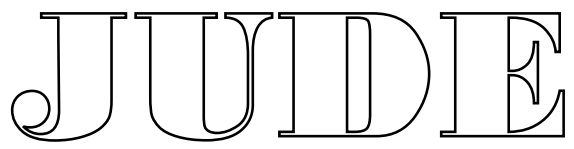

Androgyny compounds ambiguity. For most viewers, unfamiliar with the novel: Which is Jude? Title abbreviation widened accessibility, analogously to how Miramax were replacing 'the cottage industry of international art cinema' with 'massification' of adaptations' 'visual aesthetic' and audience (Collins, 2010, p.140).

\section{POLYGRAM FILMED ENTERTAINMENT PRESENTS IN ASSOCIATION WITH BBC FILMS A REVOLUTION FILMS PRODUCTION}

BBC involvement promises quality: costume drama recognizable worldwide. The production company meant little: if noticed, perhaps iconoclasm or irreverence. 
Hardly known, Winterbottom's name above the title was conventional. Placement nevertheless asserts authorship alongside Hardy, promoting Winterbottom at the boundary of fame. ${ }^{2}$ The Daily Mail reckoned him Britain's 'best young director' (1996); The Guardian among 'our brightest prospects' (Malcolm, 1996). Auteurist orientations imposed preferred meanings through interviews.

\section{"JUDE" \\ CHRISTOPHER ECCLESTON KATE WINSLET \\ LIAM CUNNINGHAM RACHEL GRIFFITHS JUNE WHITFIELD}

Filmgoers knew Griffiths from Muriel's Wedding (Hogan, 1994), a massively profitable Australian-French romantic comedy drama, underscoring need for overseas, and female, appeal. Comedienne Whitfield's incongruous casting inaugurates another enigma.

EDITOR TREVOR WAITE SCREENPLAY HOSSEIN AMINI

BASED ON THE NOVEL “JUDE THE OBSCURE” BY THOMAS HARDY

Small print identifies the novel. 'Based on' is looser than 'major screen adaptation'. Hardy, as Jude insists, straddles classic and modern writing. Sanctimony confronted his book. Readers were scandalized; a bishop burned it (Hardy, 1957, p.vi).

\section{EXECUTIVE PRODUCERS STEWART TILL MARK SHIVAS ASSOCIATE PRODUCER SHEILA FRASER MILNE PRODUCER ANDREW EATON DIRECTOR MICHAEL WINTERBOTTOM}

Winterbottom lists Jude among 'favourite books' (Smith, 2011, p.101). Nevertheless, even a director with his own company would hardly make a feature impulsively. Hardy was 'author of the moment' (Higson, 2003, p.18), with ten adaptations between 1994 and 2008. Genre demands difference within similarity - another writer after E.M. Forster and Jane Austen cycles - and Hardy prefigures 'postmodern anxieties and uncertainties' (Wright, 2005, p.4).

But other considerations prevailed. Copyright lasted fifty years posthumously, making Hardy available in 1978; a European Union Directive (adopted 1 January 1996) extended it to seventy. This presumably affected neither films in development nor post-1998 releases. ${ }^{3}$ New book editions marked both boundaries of the brief proscription. Lucrative copyright reverted to Hardy's publisher, Macmillan, who intensified promotion. Competitors sought sales to cover licensing, encouraging 
adaptations: 'Read the Penguin book', Jude's poster invites. Macmillan issued six Pan editions in 1995; five became newly adapted.4

The opening

Rooks caw during the credits. These and intertitles employ white Trebuchet MS type (1996) against black. Designed for Internet use, this represented contemporaneity, tempering Biblical connotations of capitals centred against sombre background. Heritage films emphasize 'Literature and the process of writing' (Higson, 2003, p.20) - as do adaptations (Collins, 2010; Murray, 2012): Jude translating, letters received, Jude's carving, Sue's ecclesiastical signs. Jude's future, chiselling headstones, replaces vision with constrained craft to commemorate loss. These graphics evoke death's blackness, reinforced by rooks' folkloric associations.

Tensions, accordant with Hardy's 'jagged contradictoriness' (Widdowson, 1989, p.35), continue in the distributor's and production companies' cards, connoting commerce, public service broadcasting (PSB), and radicalism:

\section{POLYGRAM FILMED ENTERTAINMENT PRESENTS}

Weighing short-term loss against multinational ambitions, Phillips subsidiary PFE granted independents funding and distribution: comparative 'autonomy' alongside security (Higson, 2003, p.109).

\section{IN ASSOCIATION WITH BBC FILMS}

Jude followed BBC2's successes Middlemarch (1994) and Our Friends in the North. Middlemarch revived costume serials, combining lavishness with contemporary parallels. Ratings and reviews dispelled fears the Corporation would discontinue this costly tradition against digital competition (Morris, 1996).

Jude was well funded for a Winterbottom project and BBC co-production: among the 1990s' 'finest films', poverty, prejudice, and aspirational failure made its themes 'too grim and parochial [...] to stand much chance of recouping the $£ 5.7$ million' budget (Murphy, 2000, p.7). Not universally acclaimed, it missed the strong US opening that platform release requires (Amini, 1996). 
Its theatrical takings, however, indicate limited viewing opportunities. British cinema's 'economic revival' (Murphy, 2000, p.ix) prioritized immediate profitability. Deciding Jude was not a slow-burning crossover, distributors halted promotion. Nevertheless, Jude's austerely cinematic treatment of Hardy's themes had missed its moment: The English Patient (Minghella, 1997) and Shakespeare in Love (Madden, 1998) were imminent. These Miramax titles epitomise US-driven packaging of literature: deified authors; conflated writing, sex and reading; emotional appeal through comedy and/or melodrama; lifestyle and taste endorsement through merchandising; and academic or coterie evaluation eschewed for celebration through book clubs or on-line postings. Producer/consumer and reader/filmgoer boundaries dissolve into 'a shared community of book lovers' (Collins, 2010, p.149), validated by promotion of prize-winning titles, media attention, and films' expensive production values, international stars, and awards endorsing 'quality' and popularity.

Jude's budget enabled aerial shots and filming on Edinburgh's Royal Mile. Unlike dialogue dependence, which formerly allied period dramas to theatre and literature, Jude's telescoping into two hours embraces change. Winterbottom fuses social realism with French New Wave irreverence. References to Truffaut among others proclaim cinephiliac allegiances antithetical both to how PBS television's Masterpiece Theatre (1971-2008) valorised British literariness as an 'international gold standard of educated taste' (Collins, 2010, p.127), and to Miramax-led 'taste synergy' (171). Rejecting adaptations' 'picturesque way of seeing' (139) asserts distinct cinematic artistry.

\section{A REVOLUTION FILMS PRODUCTION}

This name and logo (red star in circle) imply an agenda. 'You've got to call it something', Winterbottom said of his and producer Andrew Eaton's company, before dubbing Cathy Come Home (1966) revolutionary for affecting many (Smith, 2011, p.52). Nevertheless, Jude's Press Pack quotes Eaton hoping to 'cause [...] provocation.'

Jude echoes British social realism: working-class anti-heroes, personifying social concerns; regional settings for individualistic, competitive, masculine pride, against grind and conformity; monochrome cinematography, naturalistic lighting and miseen-scène; 'personal poetic observation of everyday reality' (Cook, 1985, p.147). While social problems could not remain marketable overseas, subscription channels and 
video offered alternatives to mainstream fare. Towpath scenes recall A Taste of Honey (Richardson, 1961) and Jude charging into a forest The Loneliness of the Long Distance Runner (Richardson, 1962). Brutally objective sex contrasts with Miramax's 'intertwining of sexual passion with [...] literary experience' (Collins, 2010, p.149). Indeed Arabella interrupts Jude’s reading.

\section{A MICHAEL WINTERBOTTOM FILM}

Winterbottom evades political discussion, stressing 'humanistic' concerns (Smith, 2011, p.xiv). Intentions aside, Jude addresses persistent contradictions. Hardy recounts Jude blaming over-ambition: 'It takes two or three generations to do what I tried'; 'my impulses [...] were too strong not to hamper a man without advantages' (1957, p.337). The novel coincided with modernity, incipient modernism, feminism, and psychoanalysis: Sue embodies the unruly woman Freud's early work on hysteria pathologised.5

Jude's setting, following Hardy-and Scandinavian filmmakers, subjects of Winterbottom documentaries (ITV, 1989; Channel 4, 1989; BBCtv, 1995) - becomes narratively determinant, unlike heritage's space as spectacle less 'used' than 'admired' (Higson, 1996, p.118). Jude's harsh locations with cold light undercut nostalgia typified by a popular intertext, Ridley Scott's 1970s Hovis commercial: 'Britain's favourite TV ad' (YouTube). With brass band (working-class) playing Dvorak (high culture), and Yorkshire-accented voiceover, Scott appropriated tourist destination Shaftesbury (Hardy's prototype for Shaston) as northern; Winterbottom employs corresponding compositions in northern England (Beamish) for Shaston. Scott's travesty - thatched cottages glowing sepia - sentimentalized poverty and asserted One-Nation Englishness, foreshadowing 'heritage', despite industrial unrest, conflict in Ireland, bombings, financial constraint, fuel shortages, colliery disasters, and European entry. Jude complicated culture, identity, nation, and region months before Welsh and Scottish devolution. It detaches Wessex from England as Britain, romantically constructed before World War I alongside Hardy as 'great modern tragic humanist and rural annalist' (Widdowson, 1989, p.24).

Jude appropriates European traditions alongside 'national characteristics' English landscapes, restraint, 'stolid routine', even allegedly 'anti-dramatic', 'anticinematic' weather - to produce 'strong emotion' Truffaut felt Britishness deterred (1978, p.140). 'Diversity' - 'strikingly apparent', Bruce Bennett argues, 
across Winterbottom's films (2007, pp.289, 290) - characterizes Jude as a single, yet hardly univocal, text.

Winterbottom's period drama pushed 'boundaries [...] for the middle-aged middle class audiences that are the genre's mainstay' (Allison) - or were, before blockbuster marketing. Pig slaughter, forthright sex, and bloody childbirth eschew idealisation. Indecorum nevertheless follows Hardy, whose Arabella, after all, lobs a pig's penis.

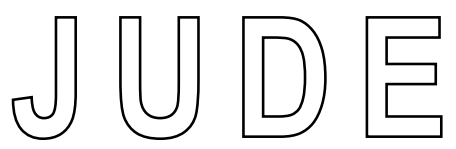

Massive white-on-black portends disruption while establishing monochromatic symbolism as a cohesive device. These capitals, starker than the trailer's, and antithetical to flowery elegance used in Howards End, suggest Godard's politicized postmodernism or Solanas and Getino's Third Cinema. But Jude recalls Loach, not Godard: juvenile Jude (James Daley) resembles Billy (David Bradley) in Kes (1969), another animal lover with circumscribed aspirations. Householders' refusal to rent to homeless parents recalls Cathy Come Home. The birth scene reminds Jeremy Strong of Poor Cow (Loach, 1967); Judith Mitchell of Cries and Whispers (Bergman, 1972). Referencing screen precursors while adapting literature proposes different 'timelessness'. Jude questions how far twentieth-century consciousness challenged inequality and morality.

Title truncation accords with streamlined adaptation, countering $1990 \mathrm{~s}$ elongations - for example, Mary Shelley's Frankenstein (Branagh, 1994) - that claim authenticity. Given the decade's individualism and putative classlessness, abbreviation foregrounds Jude as boundary challenging: thwarted personality, not 'obscure' nobody. He typifies hegemonic conflicts usually dramatized separately in period drama and social realism.

Light slits across the screen, bounding earthly oppression against sky as slim hope. A minuscule figure approaches. Variously positioned credits necessitate 2.35:1 widescreen, letterboxed into 4:3 until an intertitle masks resizing to Academy ratio. Self-reflexive or imposed for post-theatrical distribution, the shapes cross boundaries between cinematic spectacle and television's fading single play format or vibrant serialization and contemporary drama traditions. Adaptation and realism in Britain bridge both media. 
Shadows shift. Furrows approach vanishing point. Symmetry, following centred typography, asserts control, evoking cosmic determinism often univocally ascribed to Hardy. Equilibrium anchors spontaneity; Winterbottom eschews adaptations' typically studied compositions. The third shot contrasts clods against drifting clouds and a flitting rook. Structuration links earth with sky as life, physical and spiritual.

Jude, traversing the screen, paces the boundaries. Close-ups alternate with frontal and rear shots, and forward tracking from his position, inaugurating an image system of journeying, diverted and thwarted. Constricted telephoto framings isolate the individual, carving slices from reality, which nevertheless remains visible or is reinstated by wider landscape shots. This British New Wave convention fixes the protagonist in social and economic context. Lateral movement positions the spectator as observer. Alternating ocularization dissolves and reinstates boundaries separating objectivity from identification.

Telephoto shots intersperse throughout with naturally lit interiors. Minimal props and harsh sounds - latches, hobnailed footsteps - inscribe era, class and location, undermining patriotic and Utopian 'museumification' that Patrick Wright (1985) considered central to heritage policies. Sound exceeds narrative; settings apparently pre-exist. Characters, fate, and society interpenetrate, as when stonemasons' machinery counterpoints a choir-realism, but also intellectual montage, symbolizing material/spiritual, labour/scholarship conflicts hastening Jude's destruction.

ORIGINAL MUSIC

\section{ADRIAN JOHNSTON}

Melancholy folk accompaniment turns optimistic, interfacing authenticity and the ideal, conveying ambition and relating Jude to the life of the flesh - as at his wedding - as much as pastoralism. Baroque orchestration dominates in Christminster when Jude pursues Sue. Folk collections bowdlerized political opposition and bawdiness when appropriated for schools' or classical repertoires projecting Englishness, alongside Hardy's containment. 
Unusually for period drama at the time, Jude eschews splendour; 'characters wear clothes, not costumes', remarks Pamela Church Gibson (2000, p.119).

PRODUCTION DESIGNER

JOSEPH BENNETT

DIRECTOR OF PHOTOGRAPHY

EDUARDO SERRA A.F.C.

Furrows prefigure parallel, predestined lives. Tracking shots justify this conceit. Jude travels restlessly: educational pilgrimage becomes labouring for survival. Sue and Arabella's letters are narrated over Jude framed within train windows. At Arabella's return the doorknocker raps: no one, just a train's sound. Beyond highlighting rootlessness, enforced mobility, and modernity - migration and immigration, themes in Hardy, being boundary crossings nostalgic heritage reacted to - aerial shots of locomotives figure among references to Truffaut's restive Jules and Jim (1962). Jude believes he travels by free will; society, Philip French suggests (1996), lays the lines. Imagery connotes progress and constraints determined by fate, economics, prejudice, heredity (the novel's 'Curse of the Fawleys'), 'natural' law (boundaries between cousins) or individual weakness. Ploughing is, nevertheless, human imposition on nature.

\section{SCREENPLAY \\ HOSSEIN AMINI}

Amini proposed to 'destroy the heritage film from within' (Jude Press Pack) unmentioned in his published script's preface, which reports feeling 'chastened and frightened by the Director's ultimate power' (1996, p.vi). He admits not having read Hardy's novel when hired; 'desperate' for commission, Amini experienced indifference towards material remote from his 'privileged background' (p.iii). Nothing was further from emergent hybrid marketing that persuades consumers 'the movie is better because everyone involved [...] loves the novel just as much as you do' (Collins, 2010, p.180).

Yet television plays - precursors to Jude's film format - occupied boundaries between authorship, institutions, and audiences. Winterbottom downplayed any 'distinction, especially in Great Britain, where practically all films are [television] coproduced' and 'made-for-television films' screen theatrically (Smith, 2011, pp.14-15). 
Changing from televisual to cinematic projects, the BBC commissioned independents under its production quota to replicate Channel 4's co-production and integrated theatrical and broadcasting distribution, which had spawned A Room With a View, kick-starting cine-literary synergies and taste blending disadvantageous to Jude. Filmmakers within PSB, including Revolution, increasingly enjoyed freedom resembling single playwrights'. Answerable to personal vision, they could subvert expectations. (Amini, contrastingly, felt 'in the way', an employee (1996, p.vii).) 'Invisible earnings'-prestige, publicity, creative loyalty - and unexpected hits encouraged patronage and niche orientation in 'secondary' alongside mainstream markets (Murdock, 1980). Moreover, as W. Stephen Gilbert said of plays, features allowed initiation by 'individuals outside the broadcasting institutions' (1980, p.36).

Drama embraced film when studio scarcity after BBC2's arrival (1964) necessitated location shooting. Furthermore, film supported export-oriented production values. Risk-taking could be profitable, inaugurating trends: 'Film on Four' and 'Screen Two', showcased theatrically, attracted 'rather successful' ratings, Mark Shivas observed (Barr and Hillier, 1989, p.21). Nevertheless, ambitious projects distinct from entertainment demonstrated PSB credentials. Holding individuals or external companies responsible for 'attacks on established values and institutions' (Murdock, 1980, p.30) deflected criticism, and broadcasters occasionally appeared virtuous for halting unacceptable productions.

The mix, Grahame Murdock highlights, included selling 'overseas networks the one fiction commodity they can't get anywhere else - authentically English historical sagas' (p.29), even if globalized co-production now muddies this. Adaptations and dramatized royal biographies perpetuated 'pervasive images of historic England' (p.29). Winterbottom courted different criteria.

\section{BASED ON THE NOVEL ‘JUDE THE OBSCURE’ BY}

THOMAS HARDY

'Based on' tempers the advertised 'Adapted from.' Jude renounces fidelity. A forward track pans to rooks dangling from a gibbet. This Bergmanesque addition expresses what Hardy's Jude utters - 'How ugly it is here!' (1957, p.18) - and prefigures 'Little Jude's' fratricides and suicide. 


\section{STEWART TILL}

Shivas headed BBC Films and, previously, Drama. Backing Jude to the Corporation's limit, he attracted co-producers (Amini, 1996). Till, PFE's first President, increased budgets, helping art cinema compete against Hollywood (Murphy, 2000, p.4).

An editor of academic journal Movie, Shivas shared with Winterbottom, Eaton, and Amini an Oxford education; outsiders (two from modest backgrounds, Amini an Iranian) they arguably understood Jude's boundary-challenging ambitions. The film sympathizes, redoubling rejection's harshness: a working-class accent voices the Dean of Admissions' letter - narratorial commentary outside Jude's knowledge. (For Sue or Arabella's letters the voiceover is hers.) The voice may be Jude's, implying unconscious acceptance of inevitability.

A man attacks from off-screen. The 'surprised' camera reframes to follow close-up action, simulating artlessness-a social realist technique. The farmer continues beating Jude in long shot through drifting mist. The incident, recalling Pip's encounter with Magwitch in Great Expectations (Lean, 1946), culminates several similarities to that classic adaptation's opening, reiterating self-consciousness of tradition. (David Lean is one 'exception' to cinephiles' dismissal of British film for literary/theatrical contamination (Collins, 2010, p.128).) The monochrome, bleak landscape, anxious boy looking around and running, paired gibbets, harsh weather, and bird cries, inscribe homage while prefiguring the end.

\section{DIRECTOR MICHAEL WINTERBOTTOM}

'[I]mperceptible, pre-individual forces [...] of which he is in large part unaware', Lapsley and Westlake insist, shape any author, 'less constitutive than constituted' (2006, p.246). Economics, culture, industry, and ideology determine a text's 'play of its meanings' (Caughie, 1981, p.208) from which spectators negotiate significance. Relationships evident in credits and intertexts render direct, linear adaptation untenable.

Authorship becomes 'valuable' when 'it opens texts to historical forces, and pernicious insofar as it insulates films in an ahistorical cult of personality' (Gunning, 2003, p.189). Hardy - national treasure, chronicler of comical grotesques, rebel against oppression, personification of tourist destinations, Grand Old Man of Letters 
- is a popular cultural construct; Winterbottom, independent, arthouse auteur, a high cultural construct. Adaptation here problematizes the literature-cinema hierarchy of cultural capital. It contradicts the Miramax model whereby antagonistic 'taste cultures' became 'encouraged to not just enjoy the same film but somehow regard it as their own' (Collins, 2010, p.180). Jude's trailer promised this. The film, at that time unfinished, refuses.

\section{Conclusion}

This paper's methodology is provisional and exploratory. Film analysis via credits may seem analogous to judging books by covers. However, it identifies determinants that frame meaning. Bracketing out 'source' and adaptation, except for illustrative purposes, hinders or precludes prejudiced, opinionated, and subjective rush to evaluation when, typically, enthusiasm for one or the other is a precondition for comparison.

Encumbering common-sense or unexamined responses defers judgments and conclusions. Credits and trailers are less nodes than instances of congealment where, like Barthes' lexia in $S / Z$ (1974), connections are identifiable and traceable. Attention to their accumulation instead of indifference to them as boundary ritual permits dialectical montage or productive serendipity, enrichment and complication through juxtaposition, rather than inexorable flow channelled by theory or predetermined argument. Each credit interrupts logical development as space constraints preclude the impossible ideal of comprehensiveness; but as a dam restrains water, pressure of association forces new ways around. Other analysts might produce different matrices from the same material, as the present writer might offer an alternative background for meanings to resonate against by providing other emphases.

Unequal selection and highlighting are unavoidable. Barthes' 234 pages explicated a twenty-four-page tale; Turvey (1982), attempting to adapt Barthes' five 'readerly' codes to a feature film, required thirty dense pages for seven shots (sixtyseven seconds' screen time). Whether insights here outweigh unfamiliarity and uncertainty is the reader's decision. But this essay's line of flight, criss-crossing boundaries or leapfrogging territories, seeks to be guided by the text and its formation in process rather than mapped onto a prior impression. 


\section{Notes}

1 'Theatrical Trailer' on DVD. Trailers vary for different audiences. Graphic style here suggests a prerelease version before Jude's completion. Subsequent takings made expenditure on further trailers unlikely. This one illustrates agenda setting and preferred meanings ahead of critics' and audiences' interpretations.

2 During this essay's completion, Bruce Bennett published The Cinema of Michael Winterbottom (2014) subtitled Borders, Intimacy, Terror. It complements rather than duplicates or invalidates points made here.

3 The film rights' former owners cannot confirm this; archives are not easily accessible and personnel have changed.

4 Thanks to Media, Legal, and Archive departments at Macmillan for clarification.

5 Studies in Hysteria (1895) appeared the same year as Jude the Obscure. 


\section{Bibliography}

Allison, D., 2005. Michael Winterbottom. [online] Senses of Cinema. Available at: http://www.sensesofcinema.com/contents/directors/o5/winterbottom.html [Accessed 10 September 2011].

Amini, H., 1996. Jude: The Shooting Script. London: Nick Hern Books.

Art's Promised Land, 1995. [TV programme] BBCtv.

Barr, C. and Hillier, J., 1989. Interview with M. Shivas. Movie (33), pp.15-33.

Barthes, R., 1974. S/Z. Trans. Miller. New York: Hill and Wang.

Bennett, B., 2014. The Cinema of Michael Winterbottom: Borders, Intimacy, Terror. London: Wallflower Press. 2007. Very Un-British Films: Michael Winterbottom and the Cinema of Incompatibility. Yau Liu, ed. Rereading Britain Today: Essays in British Literary and Cultural Studies. Shanghai: Shanghai Foreign Language University Press. pp.285-299.

Casetti, F., 1998. Inside the Gaze: The Fiction Film and its Spectator. Bloomington and Indianapolis: Indiana University Press.

Cathy Come Home, 1966. [TV programme] BBCtv.

Caughie, J., ed., 1981. Theories of Authorship. London: Routledge/BFI.

Chariots of Fire, 1981. [Film] Directed by H. Hudson. UK.

Church Gibson, P., 2000. Fewer Weddings and More Funerals: Changes in the Heritage Film. R. Murphy, ed. British Cinema of the 9os. London: BFI. pp.115-124.

Collins, J., 2010. Bring on the Books for Everybody: How Literary Culture Became Popular Culture. Durham and London: Duke University Press.

Cook, P., 1985. Auteur Theory and British Cinema. P. Cook, ed. The Cinema Book. London: BFI. pp.147-163. 
Cracker, 1993-4. [TV programme] ITV.

Cries and Whispers, 1972. [Film] Directed by I. Bergman. Sweden.

Deleuze, G., 1977. I Have Nothing to Admit. Semiotext(e), Anti-Oedipus 2, 3.

Deleuze, G. and Guattari, F., 2004. A Thousand Plateaus. London: Continuum.

The English Patient, 1997. [Film] Directed by A. Minghella. USA/UK.

Fiske, J. and Hartley J., 1978. Reading Television. London: Methuen.

French, P., 1996. Jude review. The Observer, 10 October. p.1.

Gilbert, W. S., 1980. The Television Play: Outside the Consensus. Screen Education, (35), pp.35-44.

Great Expectations, 1946. [Film] Directed by D. Lean. UK.

Gunning, T., 2003. D. W. Griffith: Historical Figure, Film Director, and Ideological Shadow. V. W. Wexman, ed. Film and Authorship. New Brunswick and London: Rutgers University Press. pp.181-193.

Hardy, T., 1957 [1895]. Jude the Obscure. London: Macmillan.

Hearts and Minds, 1995. [TV programme] Channel 4.

Hewison, R., 1987. The Heritage Industry: Britain in a Climate of Decline. London: Methuen.

Higson, A., 2003. English Heritage, English Cinema: Costume Drama Since 1980. Oxford: Oxford University Press. , 1996. The Heritage Film and British Cinema. A. Higson, ed. Dissolving Views: Key Writings on British Cinema. London: Cassell.

Ingmar Bergman: The Director, 1989. [TV programme] Channel 4.

Ingmar Bergman: The Magic Lantern, 1989. [TV programme] ITV.

Ingold, T., 2010. Bringing Things to Life: Creative Entanglements in a World of Materials. Realities Working Papers, 15 (July). Available from: http://www.socialsciences.manchester.ac.uk/morgancentre/realities/wps/152010-07-realities-bringing-things-to-life.pdf [Accessed 5 September 2013]. 
Howards End, 1992. [Film] Directed by J. Ivory. UK/Japan.

Heavenly Creatures, 1994. [Film] Directed by P. Jackson. NZ/Germany.

Jude, 1996. [Film] Directed by M. Winterbottom. UK.

Jude preview, 1996. The Daily Mail, 10 May. p.39.

Jules and Jim, 1962. [Film] Directed by F. Truffaut. France.

Lapsley, R. and Westlake, M., 2006. Film Theory: An Introduction. $2^{\text {nd }}$ edition. Manchester: Manchester University Press.

Leitch, T., 2007. Film Adaptation and Its Discontents. Baltimore: Johns Hopkins University Press. 2003. Twelve Fallacies in Contemporary Adaptation Theory. Criticism, 45 (2), pp.149-171.

The Loneliness of the Long Distance Runner, 1962. [Film] Directed by T. Richardson. UK.

Malcolm, D., 1996. A Good Bad Time. The Guardian, 4 October, Section 2, p.8.

Mary Shelley’s Frankenstein, 1994. [Film] Directed by K. Branagh. USA/Japan.

Middlemarch, 1994. [TV programme] BBCtv.

Mitchell, J., 2005. All Fall Down: Hardy's Heroes on the 1990s Cinema Screen. T. Wright, ed. Thomas Hardy on Screen. Cambridge: Cambridge University Press. pp.76-93.

Morris, N., 1996. Lawrence's Response to Film. P. Poplawski, ed. D H Lawrence: A Reference Companion. Westport: Greenwood Press. pp.591-603.

Much Ado About Nothing, 1993. [Film] Directed by K. Branagh. UK/USA.

Murdock, G., 1980. Authorship and Organisation. Screen Education (35), pp.19-34.

Muriel's Wedding, 1994. [Film] Directed by P. J. Hogan. Australia/France.

Murphy, R., 2000. A Path through the Moral Maze. R. Murphy, ed. British Cinema of the 9os. London: BFI. pp.1-16. 
Murray, S., 2012. The Adaptation Industry: The Cultural Economy of Contemporary Literary Adaptation. New York: Routledge.

Naremore, J., ed., 2000. Film Adaptation. New Brunswick: Rutgers University Press.

Our Friends in the North, 1996. [TV programme] BBC2.

Poor Cow, 1967. [Film] Directed by K. Loach. UK.

A Room With a View, 1985. [Film] Directed by J. Ivory. UK.

Sense and Sensibility, 1996. [Film] Directed by A. Lee. USA/UK.

Shakespeare in Love, 1998. [Film] Directed by J. Madden. USA.

Shallow Grave, 1994. [Film] Directed by Danny Boyle. UK.

Smith, D., ed., 2011. Michael Winterbottom: Interviews. Jackson: University of Mississippi Press.

Stam, R., 2005. Introduction: The Theory and Practice of Adaptation. R. Stam \& A. Raengo, eds. Literature and Film: A Guide to the Theory and Practice of Film Adaptation. Oxford: Blackwell. pp.1-52.

Strong, J., 2006. Tess, Jude, and the Problem of Adapting Hardy. Literature/Film Quarterly, 34 (3), pp.195-203.

A Taste of Honey, 1961. [Film] Directed by T. Richardson. UK.

Truffaut, F., 1978. Hitchcock. London: Paladin.

Turvey, S., 1982. Barthes' S/Z and the Analysis of Film Narrative: The Searchers. Media Analysis Paper 3. London: University of London, Institute of Education.

Widdowson, P., 1989. Hardy in History: A Study in Literary Sociology. London and New York: Routledge. 1997. Obscuring Jude the Obscure. Critical Survey, (9), pp.196-103.

Wright, T., 2005. Introduction. T. Wright, ed. Thomas Hardy on Screen. Cambridge: Cambridge University Press. pp.1-7.

Wright, P., 1985. On Living in an Old Country. London: Verso. 